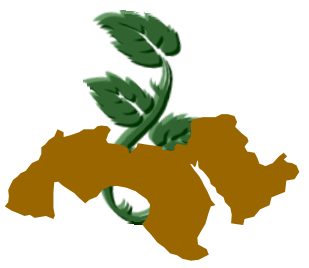

Arab Univ.

J. Agric. Sci.,

Ain Shams Univ.,

Cairo, 19(1), 247-259, 2011

\title{
EFFECT OF SOWING DATES OF THREE COWPEA CULTIVARS ON THEIR INFESTATION RATE WITH COWPEA POD BORER ETIELLA ZINCKENELLA
}

\author{
Helalia$^{1}$, A.A.R.; F.A.F. Ali'; M.F.A. Hegab' ${ }^{2}$ and Kh.A. Kamal ${ }^{1}$ \\ 1- Plant Protection Department, Faculty of Agriculture, Al-Azhar University, Nasr city, Cairo, \\ Egypt \\ 2- Plant Protection Research Institute, Agriculture Research Center, Dokki, Giza, Egypt
}

Keywords: Cowpea, Sowing dates, Cowpea pod borer, Cowpea cultivars

\section{ABSTRACT}

Field trials were conducted during 2005 and 2006 seasons at Minofia governorate to evaluate the effect of planting date of three cowpea cultivars on their infestation rate with cowpea pod borer, Etiella zienckenella. For each cowpea cultivar planted at each tested date, the numbers of bores and larvae were counted in green and dry pods as well as in dry seeds and the means were obtained to estimate the degree of insect infestations. Results indicated that, regardless the planting date in both seasons, Kream7 was the highest resistant cultivar to insect infestation followed by Kaha1 and then Kafr El Shikh1. On the other hand, regardless the cowpea cultivar, the rate of insect infestation was greatly reduced at the early plantation. Thus, selection of Kream7 cultivar and early plantation could be involved in reducing $E$. zinckenella infestation and subsequently increase the cowpea yield. These studies clearly demonstrated that several non-insecticidal approaches have great potential for cowpea pod borer Etiella zinckenella management. These approaches include some of integrated pest management strategies which can effectively prevent or reduce infestation.

\section{INTRODUCTION}

The lima bean pod borer Etiella zinckenella Treit. cause very serious damage to legume plants, such as cowpea, peas, soybean, lima bean and acacia as reported by Segara-Carmona and Barbosa (1990) and Bachatly and Abdel Malak (2000). In addition, losses caused by Etiella zinckenella to flowering and pod formation stages the two critical periods, caused $70 \%$ yield loss (Abdel Rahman, 2004). However, in some instances, however, levels of control with pesticides are not enough sufficient to reduce the damage of lima bean pod borer. Therefore, some programs were conducted to investigate several integrated management strategies which have shown potential for Etiella zinckenella control. Such strategies would reduce pesticide reliance in Egyptian legume plantations and aid in pesticides resistance management (Abdel-Galil et al 2001 b).

The use of cultural control methods may be potentially useful for cowpea pest suppression, time of sowing is a simplest form of cultural practices that has considerable influence on the level of infestation (Metwally, 1993 and Ali et al 1994).

The use of resistant host plant has been recognized with potential for certain insect pests in integrated pest management system. Metwally and Mahgoub (1992) studied the susceptibility of seventeen cowpea cultivars to E. Zinckenella infestation.

The objective of this work is to study the effect of planting time and susceptibility of three cowpea cultivars to their infestation with cowpea pod borer.

\section{MATERIALS AND METHODS}

1- Susceptibility of certain cowpea cultivars to infestation with lima bean pod borer (Etiella zinckenella Treit) at thre sowing dates under field conditions

This experiment was conducted in a private farm at Ashmoun district, Minufia governorate during 2005 and 2006 growing seasons to study the susceptibility of three selected cowpea cultivars to infestation with lima bean pod borer (Etiella zinck- 
enella Treit) at three sowing dates of 15 days intervals,i.e. April 15, May 1 and 15. The selected cowpea cultivars were supplied from Department of Horticulture, Agriculture Research Center, Ministry of Agriculture. An area of about $1 / 4$ feddan was prepared and divided into 27 plots (three plots / cowpea cultivar / planting time) in complete randomized blocks design. Normal agricultural practices were followed and no insecticides were applied. Samples were taken using direct count method and results were recorded during both growing seasons.

\section{2- Evaluation of susceptibility degree}

This experiment was conducted to evaluate the susceptibility of the tested cowpea cultivars to the infestation with $E$. zinchenella at three sowing dates under field conditions. Ten green and 10 dry pods were picked each ten days from each plot after cowpea fruit pods setting till collecting the yield. Number of holes or larvae of 10 green or 10 dry cowpea pods was counted. The mean number per pod was calculated, the percentage of infested pods was recorded for each sowing date. For the samples of dry cowpea pods, number and percentage of infested and uninfested dry seeds was recorded. Data obtained were statistically analysed by using F. Test. The means were compared according to Duncans multiple test (Snedecor and Cochran, 1971). Classification of susceptibility degree of cowpea cultivars was determined for cowpea pods and seeds based on the general mean $(x)$ and the standard deviation (SD) as reported by Chiang and Taiekar (1980) and Taiekar and Chen (1983). According to this method, cowpea cultivars may be classified into five categories according to the damage percentage because, at times, larvae may escape before sampling to complete its life cycle. The cultivars that had mean damage percentage more than $X+2 S D$ considered highly susceptible (HS), between $X$ and $X+2$ SD susceptible $(S)$, between $X$ and $X+1$ SD low resistant (LR), between $X-1 S D$ to $X-2 S D$ moderate resistant (MR) and less than $X-2 S D$ were considered highly resistant (HR).

\section{RESULTS AND DISCUSSION}

\section{1- Susceptibility of tested cultivars}

The total number of $E$. zinckenella per 10 green and 10 dry cowpea pods was used to evaluate the infestation. Susceptibility degree of each cowpea cultivar during the plant growth was determined. Furthermore, the percentage of infestation to dry seeds was calculated to determine the susceptibility degree of each cowpea cultivar to infestation with $E$. zinckenella.

The mean number of holes and $E$. zinckenella larvae during 2005 and 2006 growing seasons were shown in Tables (1 and 2) for green pods, in Tables (5 and 6) for dry pods and in Tables (9 and 10) for the dry seeds, respectively. Analysis of data revealed differences between the tested cowpea cultivars in both seasons. The highest percentage of infestation was observed in cowpea cultivar Kafr EL Shikh 1. The infestation rates was ranged from 47 to $67 \%$, from 47 to $65 \%$ and from 26 to $38 \%$ for green pods, dry pods and dry seeds, respectively. However, the lowest infestation was recorded on cowpea cultivar Kream 7 with infestation rates of (39-60\%) for green pods, (42-58\%) for dry pods and (17 - 22\%) for dry seeds. Based on the infestation rates of green pods, dry pods and dry seeds of cowpea cultivars, data listed in Tables (4, 8 and 12) revealed that Kream 7 received the lowest infestation and damages and appeared to be the highest resistant (HR) cultivar, while, Kafr EL Shikh1 cultivar was the susceptible (S) one during both 2005 and 2006 seasons. In this respect, (Painter, 1968) classified host-plant resistance to insects into three categories: Non preference resist, antibiosis resist and host-plant tolerance. These categories are mainly depend on plant characteristics (chemically or physically or both) that discourage insect attack, and all of them are genetically controlled in the host-plant. The same author added that the unique advantages of resistant cultivars are that irrespective of the level of resistance, they reduce insect numbers at all levels of infestations, are accumulative in there effect, and are compatible with other methods of insect control.

\section{2- Effect of planting date}

Three planting dates, 15 April, 1 and 15 May, were applied during 2005 and 2006 seasons to evaluate the effect of planting date on the rate of infestation with $E$. zinckenella. Data listed in Tables $(1,2,5,6,9,10)$ revealed highly significant differences between the three dates in both seasons. The infestation percentages in the early plantations (15 April) ranged between 39 and $47 \%$ for green pods, 42 to $48 \%$ for dry pods and 17 to $26 \%$ for dry seeds. In 1 May plantation, the corresponding infestation rates were 42 to $51 \%, 46$ to $52 \%$ and 17 to $31 \%$ for green pods, dry pods and dry seeds, respectively. On the other hand, the corresponding infestation rates in 15 May plantations raised to (60 to $67 \%$ ), (58 to $65 \%$ ) and (22 to $38 \%)$. 
Data tabulated in Tables (3, 7 and 11) clearly indicated that the infestation rate of cowpea cultivars with $E$. zinckenella through both seasons 2005 and 2006 was obviously sowing date dependent. The lowest infestation rate was observed at the early planting date (15 April) while it was recorded high rates at mid and late planting dates (1 and 15 May).

Results could be agreed with those obtained by Abdel-Galil et al (2001 a) who found that early planting date (April 20) showed the lowest infestation percentage with $E$. zinckenella. In addition, the cowpea cultivar Kream 7 represented low percentage of shattering pods and did not suffer from high infested green, dry pods and dry seeds as agreed with Abdel-Rahman (2004) and Abdel-Rahman (1999). Tohamy (2005) has tested certain cowpea cultivars in difference planting dates, he suggest that using high resist cultivars in early planting dates are more suitable and achieve low infestation. These findings may be attributed to the physical and chemical characteristics of these cultivars as reported by Ramalho et al (1977), however, the early planting dates showed the lowest infestation percentage by $E$. zinckenella followed by the late planting dates, these findings are perhaps due to the avoidance of high population of $E$. zinckenella infesting cowpea pods as mentioned by Metwally and Mahgoub (1992).

In conclusion, the obtained results assured that planting time and kind of cultivar have pronounced effect on the infestation rate of $E$. zinckenella on cowpea plantations and production.

\section{REFERENCES}

Abdel-Galil, F.A.; M.A.A. Morsi; S.H. Mohamed and M.A.M. Amro (2001 a). Control strategy of the lima bean pod borer Etiella zinckenella Treit. Infesting compeer in the new reclaimed areas. Bull. Fac. Agric., Cairo Univ., (1): 2532.

Abdel-Galil, F.A.; A.A.M. Mohamed and H.M. Samy (2001 b). Determination of the relative susceptibility and field losses in certain cowpea cultivars damaged by the lima bean pod borer in the arid ecosystems. Proc. $2^{\text {nd }}$ Scientific Conference of Agricultural Sciences. Assiut, Egypt, 2: $567-572$.

Abdel-Rahman, M.A. (1999). Ecological Studies on Certain Arthropod Pests Infesting Selected Cowpea Cultivars and Control Strategy in Arid-ecosystems, pp. 110-138. Ph.D. Thesis in Plant Protection. Faculty of Agriculture, Assiut university, Egypt.

Abdel-Rahman, M.A. (2004). The influence of plant characteristics on the field infestation and resistance status of certain cowpean cultivars to the Lima bean pod borer Etiella zinckenella Treit and the southern compeer weevil callosobruchus maculatus (fabricas). Proc. Sec. Int. Conf. for Develop. and the Env. In the Arab World. Assiut Univ., Egypt, Center for Envi.,pp. 1-15.

Ali, M.A.; A.S. El-Khouly; I.L. Ibrahim and S.A. Naga (1994). Effects of cropping systems and time of planting of maize and cowpea on their infestation by aphids. Bull. Ent. Soc. Egypt, 72: 259-267.

Bachatly, M.A. and V.SH. G. Abdel Malak. (2000) Evaluation of infestation and damage of cowpea by the pod borer Etiella zinckenella Treitschke (Lepidoptera:" pyralidae) in Egypt. J. Agric. Res. 79(2): 489-497.

Chiang, H.S. and N.S. Taiekar (1980). Identification of sources of resistance to the beanfly and two other agromized sties in soybean and mungbean. J. Econ. Entomol. 73: 197-199.

Metwally, Samia,A.G. (1993). The effect of planting date and certain climatic factor on the fluctuations of Etiella zinckenella Treit. Infesting cowpea in Qualyobia Governorate. Bull. Entom. Soc. Egypt, 71(1): 1-7.

Metwally, Samia A.G. and M.M.A. Mahgoub (1992): Relative susceptibility of some cowpea varieties to Etiella zinckenella Treit with special references to the enzyme activities, reducing sugars and soluble proteins. Egypt J. Bio. Pest Cont., 2(2): 103-107.

Painter, R.H. (1968). Insect Resistance in Crop Plots. pp. 347-352. Univ. Press of Kansas, Lawrence and London.

Ramalho, F.S.; R.C.R. Machado and M.M. Albuquerque (1977). Study on the relation between the hardness of the pod and resistance to Etiella zinckenella Treitschke, 1832, in beans ( Phaseolus vulgaris L.). Anals Soc. Entomol. Brazil, 6(2): 138-242.

Segara-Carmona, A. and P. Barbosa (1990). Influence of patch plant density on harbivory levels by Etiella zinckenella (Lepidoptera: Pyralidae) on Glycine max and Crotalaria pallida. Environ. Entomol. 19(3): 640-647.

Snedecor, G.W. and W.G. Cochran (1971). Statistical Methods. lowa State Univ. Press, Ames, lowa, USA.

Taiekar, N.S. and B.S. Chen (1983). Identification of sources of resistance to lima bean pod borer (Lepidoptera: pyralidae) in soybeen. J. Econ. Entomol., 76: 38-39.

Tohamy, H.T. and G.A. El-Hafez (2005). Integrated crop management system for controlling cowpea pod worm, Etiella zinckenella triet in relation to soybean yield at mini and new valley regions. Egypt. J. Agric. Res., 83(3): 1079-1097. 